\title{
SOLIDARNOST - STOŽERNI POJAM KATOLIČKOG SOCIJALNOG NAUKA
}

Sažetak: Rad tematizira pojam solidarnosti kao ključni pojam katoličkog socijalnog nauka. Tekst predstavlja logični nastavak autorova spoznavanja problema solidarnosti od 80-ih godina do danas, napose sinergijski učinak sociologijsko-pravnog uvida $s$ teologijskim uvidom koji u hrvatskim uvjetima raste posebice u razdoblju od 1995. do 2005. godine kada teološka misao daje značajan obol razumijevanju solidarnosti i njezinu pojmovnom razlučivanju od drugih sličnih pojmova kao što su karitativnost, milosrde, bratstvo etc. Solidarnost se pokazuje kao samosvojan, važan pojam čitavog niza društvenih znanosti, a napose je značajna s teologijskog motrišta kao najvažnija krepost katoličkog socijalnog nauka. Osim etimologijske razine uvida u solidarnost ističe se i njezina neupitna društvena uloga, kao i njezin integracijski potencijal.

Ključne riječi: $\quad$ solidarnost, katolički socijalni nauk, bratstvo, milosrđe, karitativnost

Tematiziranje pojma solidarnosti može se na prvi pogled činiti posve anakronim i neaktualnim, budući da je riječ o pojmu koji širinom uporabe koja seže od kolokvijalnog pristupa pa do ozbiljnih znanstvenih rasprava i ne zaslužuje osobitu potrebu za ozbiljnijim pristupom. Takvom razmišljanju svesrdno pripomažu i procesi industrijalizacije, urbanizacije, specijalizacije, profesionalizacije, scijentizacije, informatičke revolucije, umreženog društva, druge moderne etc. koji na svoj način predstavljaju negaciju solidarističkog načina življenja u njegovu tradicijskom smislu.

S druge strane, pokazuje se da dublji uvid u pojam solidarnosti svjedoči da je dugo postojala značajna teorijska praznina u našim društvenim znanostima u svezi s navedenim pojmom te da on nije u dostatnoj mjeri teorijski razrađen, izuzmemo li teologijske tekstove unutar posljednjih 20-ak godina, pri čemu imamo na umu da je solidarnost otada razmjerno dobro obrađena na razini etimologijskog uvida kao i pokušaja jasnog pojmovnog definiranja.

Potrebu za izučavanjem ovog tradicionalnog pojma unutar društvenih znanosti naglašava i činjenica da između različitih društvenih i povijesnih epoha postoji i značajan kontinuitet,

* Dr. sc. Duško Lozina, redoviti profesor u trajnom zvanju na Katedri za upravnu znanost Pravnog fakulteta Sveučilišta u Splitu. Domovinskog rata 8, 21000 Split, Republika Hrvatska. Adresa e-pošte: duskolozina7@gmail.com. ORCID: https://orcid. org/0000-0002-9237-9630. 
što se očituje i u okolnosti da je solidarnost postojala i jučer kao i danas, istina bitno drukčije društveno konfigurirana. Uznapredovali proces društvene diferencijacije, kao pandan procesu integracije i globalizacije, pod koji možemo supsumirati i solidarnost kao jedan od vidova povezanosti, rastače tradicionalni smisao pojma solidarnosti, ali stvara istodobno i realnu pretpostavku za nastanak novih oblika solidarnosti, kojih je bitno obilježje da su interesno i institucionalno utemeljeni.

Solidarnost kao značajni teorijski pojam mijenjala je svoju konotaciju u zavisnosti od povijesnog trenutka. Nekada jedna od osnovnih spona suradnje i povezivanja ljudi na globalnom planu, solidarnost je s vremenom izgubila značenje relevantne socijabilne sile kako u mikrosustavima (posebice na teritorijalnom i funkcionalnom planu) i dalje predstavlja važnu homogenizirajuću snagu, a potencijalno to može biti iznova na globalnom planu, u slučaju nekih izvanrednih i izuzetnih situacija u kojima se može naći određena društvena zajednica, kao što su npr. rat, elementarne nepogode velikih razmjera itd.

Rasprava o solidarnosti, sama po sebi, istodobno je i rasprava o ljudskoj prirodi pa u tom smislu nužno dospijeva na antropologijsko područje. Solidarnost shvaćena kao jedan od mogućih oblika povezanosti između ljudi predstavlja izraz čovjekove socijabilnosti, dakle, one karakteristike čovjeka koja se u teoriji naglašava kao jedno od bitnih čovjekovih obilježja, još od antičke epohe, što je zasigurno najpregnantnije iskazao Aristotel svojim učenjem o čovjeku kao "političkoj, odnosno društvenoj životinji”.

Ovom zgodom mislimo da bi trebalo barem naznačiti jednu od temeljnih oznaka solidarnosti, a to je njezina ambivalentnost. Naime, kako je cjelokupna dosadašnja povijest čovjeka na neki način obilježena sukobom opozitnih silnica, tj. procesima približavanja i udaljavanja, integrativnim i dezintegrativnim gibanjima, dijalektikom dobra i zla, nema onda nikakvog prijepora da i pojam solidarnosti nosi u sebi, kao trajni pečat, karakteristiku ambivalentnosti.

Namjera je ovog rada da prije svega progovori o etimologiji pojma solidarnosti te da ga pokuša barem približno definirati kako bismo ga mogli jasno razgraničiti od nekih drugih srodnih pojmova kao što su bratstvo, karitativnost, milosrđe, prijateljstvo itd.

\section{POVIJEST POJMA SOLIDARNOSTI}

Poput drugih značajnih teorijskih pojmova i pojam solidarnosti ima svoju povijest. Riječ je o pojmu koji se susreće u mnogim znanstvenim disciplinama iz korpusa društvenih znanosti, ali je i u čestoj uporabi u svakodnevnom jeziku i govoru. Upravo ta rasprostranjenost pojma solidarnosti i učestalost njegove primjene, kako u strogom jeziku znanosti tako i u kolokvijalnom govoru, otvaraju i neke nedoumice vezane uz značenje tog pojma jer se on često poistovjećuje s nekim drugim srodnim pojmovima kao što su altruizam, bratstvo, karitativnost, prijateljstvo itd. I kraj okolnosti da izraz solidarnost imade svoj korijen u latinskom jeziku, ipak je riječ o novovjekovnom pojmu, nastalom u francuskoj kulturnoj sredini, u prvoj polovini 19. stoljeća. Kao tvorac riječi solidarnost najčešće se spominje francuski teoretik Pierre Leroux (1797.-1871.), koji ga je prvi put spomenuo u svom djelu L’Humanité socialiste iz 1839. godine. Pierre Leroux zapravo transponira pojam solidarnosti iz juridičkog u filozofijski jezik, a poslije će on postati najvažnijim pojmom kršćanskog socijalnog nauka. "Za njega solidarnost 
nije samo osjećaj već i dužnost, i na njoj se ostvaruje utemeljenje prava”. ${ }^{1}$ Mišljenje da je upravo Pierre Leroux otac izraza solidarnost može se susresti i u našoj pravnoj teoriji, ali i drugdje. ${ }^{2}$ Ipak, postoje i autori koji smatraju kako je pojam solidarnost nastao i nešto prije. ${ }^{3}$

Hauke Brunkhorst naglašava da je solidarnost potpuno moderan pojam, a kao njegovo ishodište vidi Francusku revoluciju. Tijekom revolucije još nije dopiralo solidarité nego fraternité. U tom smislu ovaj autor naglašava da "tijekom 19. stoljeća pojam solidarnosti se prvo pojavljuje uz pojam bratstva, da bi nakon europske revolucije 1848. god. preuzeo njegovo mjesto - prvo u radničkom pokretu pod utjecajem Marxa i Lassallea, a onda na kraju stoljeća u sociologiji, u jurisprudenciji, danas također u ustavnim tekstovima i međunarodnim sporazumima o ljudskim pravima. ${ }^{4}$ Semantika pojma solidarnosti proizlazi osim iz rimsko-pravnih izvora još iz dvaju izvora: "Jedan potječe od pagansko-republikanske sloge (lat. concordia) i građanskog prijateljstva (lat. amicitia), drugi od biblijsko-kršćanskog bratstva (fraternitas) i ljubavi prema bližnjemu (caritas)."

Solidarnost je za Brunkhorsta pravni pojam. "Rimsko-pravni pojam in solidum znači obvezivanje za cjelinu, zajedničko jamstvo, zajednički dug, zajedničku obligaciju: obligatio solidum. Jedan za sve, svi za jednoga. Tako već obligatio in solidum u mediju apstraktnog prava povezuje strane osobe, komplementarne uloge, heterogene interese. ${ }^{6}$ Za Brunkhorsta "solidarnost nije drugo lice pravednosti, ona je naprotiv ništa drugo do demokratsko ostvarenje individualne slobode. Dok se formula općeg dobra starorepublikanski odnosi na objektivno spoznatljivo kolektivno dobro 'solidarnost' ima iz temelja individualističku formu".?

Za ovog autora solidarnost nema svoje uporište u zajednici, nego u društvu. "Solidarnost nije samo solidna, solidarnost je također robusna i zbog toga kao nijedan drugi pojam sposobna odražavati zagrade između različitih modusa socijalne i sistemske interakcije društva."

\section{ZNAČENJE POJMA SOLIDARNOSTI}

Pojam solidarnosti (engl. solidarity, franc. solidarité, njem. Solidarität, španj. solidaridad) ima korijen u latinskom jeziku. Taj izraz dolazi od riječi solidus ${ }^{9}$ što znači tvrd, čvrst, valjan, samotvoran, krupan. Prema analogiji s tim i solidarnost označava jednoglasnost, suglasnost,

1 Gioacchino Nicoleti, Solidarismo u: Novissimo Digesto Italiano, Unione Tipografico - Editrice Torinese, Torino, vol. XVII, 836, 1970.

2 U hrvatskoj pravnoj znanosti takav stav zastupa Berislav Perić, Solidarizam u teoriji prava, Zbornik radova Pravnog fakulteta u Zagrebu, Zagreb, 3-4/1954., str. 267. Isti stav može se naći i u: Wilhélm Bernsdorf und Friedrich Bülow, Wörterbuch der Soziologie, Ferdinande Enke Verlag, Stuttgart, 462, 1955.

3 Tako npr. Veselin Brković u svojoj doktorskoj disertaciji “Pojam solidarnosti u samoupravnom društvu” obranjenoj 1979. na Pravnom fakultetu u Beogradu, kaže da se riječ solidarnost prvi put spominje u francuskom jeziku 1804. godine, donošenjem Code civila.

4 Hauke Brunkhorst, Solidarnost. Od građanskog prijateljstva do globalne pravne zajednice, Multimedijalni institut Beograd/ Zagreb, 2004., str. 9.

5 Ibidem, str. 11.

6 Isto, str. 10.

7 Isto, str. 12.

8 Isto, str. 14.

9 Mirko Divković, Latinsko-hrvatski rječnik, Kraljevska zemaljska tiskara, II. izd. 1900., str. 990. 
složnost, jednodušnost, jednako mišljenje, ali i zajednicu interesa, uzajamnu odgovornost, svijest o potrebi zajedničkog djelovanja. ${ }^{10}$

Pridjev solidaran (franc. solidaire) znači još i prijateljski, povezan s nekim (zbog zajedničkog nazora, djelatnosti, odgovornosti); složan, suglasan, jednodušan, sumišljenički, suodgovoran, obostran, uzajamno odgovoran. ${ }^{11}$

U francuskom jeziku solidarnost označava stanje u kojem se više osoba obvezuju jedni za druge, a isto tako i uzajamnu zavisnost između ljudi. ${ }^{12} \mathrm{U}$ ruskom jeziku spominju se ova značenja solidarnosti: a) istovjetnost misli, jednodušje (sloga), zajednički interes, aktivna sklonost mišljenju ili radnjama; b) zajednička odgovornost. ${ }^{13} \mathrm{U}$ engleskom jeziku solidarnost se, među ostalim, shvaća i kao zajednica interesa. ${ }^{14} \mathrm{U}$ njemačkom jeziku najvažnija značenja riječi solidarnost jesu: 1) "solidarnost označava uvijek jedno stanje, u kojem se mnoštvo vlada kao jedinstvo; 2) to ponašanje ima uvijek praktički smisao koji se uvijek potvrđuje putem uznemiravajućih utjecaja vanjskog svijeta; 3 ) njegov smisao je obrana od takvih smetnji, zahvata ili nasrtaja; 4) solidarnom ponašanju je podloga moralno mišljenje zajednice. Pritom zajednica ne znači ujedinjenje u praktične svrhe, ne interesno ujedinjenje, nego jedno unutarnje ujedinjenje, jedno stanje unutarnje povezanosti, koje premošćuje duboki rascjep koji inače dijeli pojedine ljude od drugih bića i stvari." ${ }^{15}$

Pozorna raščlamba mogućih značenja izraza solidarnost pokazala bi da se njime podrazumijeva postojanje visokog stupnja suglasnosti između pojedinaca koji se nalaze u određenom društvenom odnosu; nadalje da ti pojedinci imaju svijest o potrebi usuglašavanja interesa koji ih vezuju u realizaciji nekog cilja, kojemu kao grupa tendiraju; na koncu pretpostavlja se određeni kvantum uzajamne odgovornosti između pojedinaca. Solidarnost tako shvaćena predstavlja oznaku za sklad i red, odnosno negira nesklad i nered. Ona predstavlja značajnu integrativnu silu koja u paralelogramu sila oblikuje životni prostor čovjeka.

\section{TIPOLOGIJA SOLIDARNOSTI}

Paralelno s porastom interesa za solidarnost kao društvenu pojavu tekao je i proces klasificiranja i sistematiziranja pojma solidarnosti, što rječito govori o njegovoj zrelosti i razvijenosti. Danas postoje najrazličitije klasifikacije tog pojma, kao što su:

- prirodna solidarnost i moralna solidarnost. Moralna solidarnost je “jedinstvo volja i odanost uzajamnosti između ljudi"16

\footnotetext{
10 Bratoljub Klaić, Rječnik stranih riječi, Nakladni zavod Matice hrvatske, Zagreb, 1984., str. 1248.

11 Opća enciklopedija, Jugoslavenski leksikografski zavod, Zagreb, III. izd., 1981., str. 563.

12 Grand Larousse Encyclopédique, Librairie Larousse, Paris, t. 9, 1964., str. 894.

13 Boljšaja sovjetskaja enciklopedija, Gosudarstvenoe naučnoe izdateljstvo, Moskva, II. izd., 1957., str. 21.

14 Webster's Seventh New Collegiate Dictionary, G. and C. Merriam Company, Springfield, Massachusetts, USA, $1961 .$, str. 831.

15 Alfred Vierkandt, Solidarität u Wilhelm Bernsdorf und Friedrich Bülöw, Wörterbuch der Soziologie, Ferdinand Enke Vellag, Stuttgart, 1955., str. 463. 
- prirodna i društvena solidarnost - takvu distinkciju predlaže René Le Senne. Prirodna solidarnost je objektivno nužna, ogleda se u međuzavisnosti ljudi. Društvena solidarnost predstavlja obvezu određene vrste, koja se sastoji u tome da onaj koji je superioran ima obvezu zaštititi inferiornog ${ }^{17}$

- negativna i pozitivna solidarnost - to razlikovanje zastupa Pierre Laruque. Prema njemu negativna solidarnost se manifestira u stajalištu prema drugim klasama. Suprotno tome, pozitivna solidarnost je veoma snažna unutar radništva, a mnogo je manja u srednjim slojevima ili kod seljaštva. ${ }^{18}$

Ovoj razlici je bliska i Durkheimova distinkcija solidarnosti na mehaničku i organsku. ${ }^{19}$ Jedna i druga tipologija uzimaju kao kriterij razlike dosegnuti stupanj društveno-gospodarstvenog razvitka, odnosno stupanj društvene diobe rada. U teoriji se još spominju i sljedeće vrste solidarnosti: "pasivna i aktivna solidarnost", grupna solidarnost, klasna solidarnost, interesna solidarnost itd.

\section{POJAM SOLIDARNOSTI I POJAM INTEGRACIJE}

Povijesno promatrano solidarnost je jedno od mogućih načela društvene integracije. Osim solidarnosti kao značajna integracijska načela spominju se još i vlast te kontrola informacija. ${ }^{20}$ Sva navedena načela povezanosti predstavljaju načine kojima određena društvena skupina, pleme, klasa, kasta ili sloj reagiraju na pritisak neizvjesnosti. Metodički razlozi upućuju na potrebu da se objasni značenje izraza integracija, kao višeg rodnog pojma u odnosu prema pojmu solidarnosti. Integracija je jedan od polova diobe rada, čiji je drugi pol inkarniran u procesu društvene diferencijacije, koji znači zamjenjivanje jednog elementa u sustavu s dva ili više elemenata. Budući da svaki novostvoreni element u sustavu ima tendenciju da čuva svoju funkcionalnu autonomiju ili polje slobode, smjer djelovanja usmjeren je dakle centrifugalno u odnosu prema sustavu (iako ne nužno), kao egzistencijalna nužnost sustava javlja se njegova težnja da neutralizira takvo djelovanje, odnosno da drži pripadajuće elemente na okupu.

"Podrvgavanje svih elemenata sistemskom pravilu, njihovo uklapanje u sistemski oblik, ograničavanje sistemskim načelom, redukciju na zajednički nazivnik sistema zvat ćemo integracijom." ${ }^{21}$ Drugim riječima kazano, integracija predstavlja dominaciju monizma nad pluralizmom, pobjedu općeg nad pojedinačnim, nadmoć mirovanja nad kretanjem (iako je to mirovanje samo relativno), sigurnost nad neizvjesnošću, rutine i iskustva nad novim.

Od brojnih modela integracije spomenut ćemo ovaj:

1. kulturnu integraciju - ona implicira skladnost između kulturnih standarda

17 René Le Senne, Traité de Morale Generale, Presses Universitaires de France, Paris, 1961., str. 667., a cit. prema Aleksandar Todorović, Solidarnost i radnička svijest u Zborniku, Solidarnost i samoupravljanje, Centar za političke studije, Novi Sad, 1971. , str. 119.

18 Pierre Laruque, Les Classes Sociales, Presses Universitaires de France, Paris, 1959., str. 17., a cit. po Todorović, str. 123.

19 Emilé Durkheim, De la division du travail social, Presses Universitaires de France, Paris, 1960., str. 100.

20 Više o tome u: Eugen Pusić, Razvedenost i povezanost, Encyclopaedia Moderna, Zagreb, 1974., str. 127.-155.

21

Ibidem, str. 72. 
2. normativnu integraciju - ona podrazumijeva sklad između kulturnih standarda i ponašanja osoba

3. komunikativnu integraciju - podrazumijeva opseg kojim mreža komunikacije prožima društveni sustav

4. funkcionalnu integraciju - ili stupanj uzajamne zavisnosti između elemenata sustava podjele rada.

Posljednja tri tipa integracije mogu se podvesti pod društvenu integraciju. ${ }^{22}$

Integracija i dezintegracija nalaze se u određenom dijalektičkom koneksitetu, odnosno javljaju se simultano, a ne sukcesivno. Potrebno je, također upozoriti na vrijednosnu neutralnost procesa integracije i procesa dezintegracije jer se najčešće susrećemo sa sklonošću da integracijske procese ocjenjujemo pozitivno, a dezintegracijske negativno. Vrijednosnu konotaciju tih procesa valja tražiti zato unutar određene grupne dinamike. ${ }^{23}$

\section{DEFINIRANJE SOLIDARNOSTI}

Većina definicija solidarnosti opterećena je jednostranošću i nepotpunošću. Ta objekcija je prije svega rezultat činjenice što je solidarnost sama po sebi višeznačan pojam. Ona se, naime, jednom tretira ponajprije kao etičko-psihološki fenomen, dok se drugom zgodom naglašava njezino sociološko značenje jer ona predstavlja modus vivendi u nekim društvenim grupama (zajednici, kasti, klasi itd.). U ovom kontekstu valja upozoriti na jednu vrlo važnu Durkheimovu napomenu. On je smatrao da je solidarnost vrlo nepogodna za egzaktno istraživanje zbog toga što je riječ o nemjerljivoj veličini.

"Društvena solidarnost je izraziti društveni fenomen koji je, sam po sebi, nepogodan za točno promatranje i, osobito, mjerenje" - kaže Durkheim. ${ }^{24}$

Neke definicije solidarnosti (od mnogih) koje će biti spomenute, ipak bismo uvjetno rečeno mogli grupirati u nekoliko skupina:

a) psihološko-teleološke

b) etičko-teleološke

c) normativno-sociološke.

a) Psihološko-teleološke definicije solidarnosti polaze od činjenice da solidarnost predstavlja prije svega osjećaj ili "koheziju" koji drže na okupu pripadnike određene zajednice te da je to presumpcija za realizaciju određenih ciljeva, interesa ili vrijednosti. Kao primjer ovog tipa definicija solidarnosti navodimo sljedeće definicije:

22 Angell, Robert Cooley, Social integration, International Encyclopaedia of the Social Sciences, The Macmillan Company and The Free Press, New York, Vol. VII, 1972., str. 381.

23 Rudi Supek, Integracijski i dezintegracijski procesi u društvu "prelaznog perioda", Sociologija, 2-3, Beograd, 1983., str. 145.182. 
“Solidarnost se najčešće određuje kao 'kohezija' neke društvene skupine ili društva u cjelini, kao uvjet njihovog postojanja i kao povezana s njihovim vrijednostima i ciljevima." ${ }^{25}$ Ili druga definicija: "Društvena solidarnost - osjećaj što veže pripadnike neke društvene grupe da su svi oni povezani u dobru i zlu i da je sloboda pojedinca ograničena interesima grupne cjeline za ostvarenje kojih se svi moraju skupno zalagati." 26

b) Etičko-teleološke definicije vide u solidarnosti prije svega moralni fenomen koji postaje pretpostavka za ostvarenje određenih zajedničkih ciljeva, težnji i interesa. "Solidarnost je moralna veza koja spaja pripadnike jedne društvene zajednice ili političkih i drugih organizacija koje se bore za određene zajedničke ciljeve. Ona se izražava kao osjećanje povezanosti vlastitih težnji i interesa sa širim interesima zajednice odnosno pokreta ili pojedinih njegovih dijelova i manifestira se kao spremnost da se prema tome usklađuju vlastita aktivnost i držanje."27

c) Normativno-sociološke definicije solidarnosti polaze od shvaćanja da je solidarnost realni društveni odnos koji pred sudionike u tom odnosu postavlja određene zahtjeve.

“Solidarnost je takav društveni odnos u ograničenoj skupini ljudi gdje se normativno i u pravilu uspješno postavlja zahtjev da pojedinac svoje osobne interese pod određenim uvjetima podredi interesima drugih, a u isti mu se mah stavlja u izgled da će drugi pod određenim uvjetima svoje interese podrediti njegovima." 28

Ova definicija, kao što se vidi, sugerira da su pripadnici solidarističke skupine načelno ravnopravni, da imaju podjednake izglede za zadovoljavanje interesa te da je solidaristička skupina ograničene veličine.

Osim spomenutih definicija solidarnosti postoje i druge, koje u eksplikaciji navedene pojave polaze od činjenice da solidarnost postaje načelo kolektivne pravednosti te da kao takva biva sankcionirana pozitivnim zakonodavstvom u mnogim zemljama. Postoje i autori koji eksplicitno ne definiraju solidarnost, ali smatraju da postoje elementi s pomoću kojih se ona može definirati. Takvi autori imaju u vidu jedan općenitiji smisao solidarnosti te smatraju da postoje dva tipa solidarnosti. Osnovna razlika između ta dva tipa solidarnosti jest širi društveni sklop unutar kojeg se razvija solidarnost. Dok je kod prvog tipa solidarnosti taj društveni kontekst određen procesom društvene diferencijacije, dotle kod drugog tipa solidarnosti taj društveni sklop podrazumijeva zajednicu koja u punoj mjeri afirmira društvenost.

Elementi za definiranje solidarnosti (tip I) bili bi sljedeći:

- postoji međuzavisnost ili zajedništvo interesa

- postoji svijest o osobnim i o društvenim, grupnim interesima i njihovoj vezi

- iz međuzavisnosti interesa proizlazi i zajednička aktivnost

- osobni interes ili interes vezan za grupu u žarištu je naše aktivnosti

- pomoć koja se ukazuje ne mora biti pomoć u nevolji, nego i u rastu i razvoju

25 Sociološki leksikon, Savremena administracija, Beograd, 1985., str. 658.

26 Bosanac Milan; Mandić Oleg; Petković Stanko, Rječnik sociologije i socijalne psihologije, Informator, Zagreb, $1977 .$, str. 126.

27 Politička enciklopedija, Beograd, 1975., str. 1018.

Eugen Pusić, Razvedenost i povezanost, Encyclopaedia Moderna, Zagreb, 1974., str. 130. 
- računa se izravno ili neizravno na uzvraćanje

- cilj u povodu kojega postoji solidarnost nije element definicije

- širi društveni kontekst u kojem se razvija ovakva solidarnost otuđeni su ljudski odnosi.

Elementi za definiciju solidarnosti (tip II) jesu:

- postoji međuzavisnost ili zajedništvo interesa

- postoji svijest o zavisnosti interesa

- pomoć koja iz toga proizlazi nije sračunata na uzvraćanje, nesebična je

- pomoć se ne pruža samo u nevolji, nego i u rastu i razvoju

- optimalni društveni kontekst za ovu solidarnost jest zajednica u kojoj je razvijena puna društvenost, u kojoj se drugi osjećaju kao najveća potreba. ${ }^{29}$

Solidarnost bismo dakle definirali kao normativno (u širem smislu riječi) - sociološku kategoriju, odnosno društveni odnos u ograničenoj skupini, utemeljen na emocionalnom stavu zajedništva, unutar kojeg sudionici usklađuju svoje interese, težnje i aktivnosti i koji obilježava određena vrijednosna dvoznačnost. Kondenzirano iskazano, solidarnost predstavlja odgovornost jednoga za sve i svih za jednoga. Na taj način štiti se sigurnost i jača se zaštita kako pojedinaca tako i zajednice zbog uzajamne skrbi pojedinca za zajednicu i zajednice za pojedinca (što može biti rezultat spontanosti ili pak sankcionirano na neki drugi način).

\section{RAZGRANIČENJE POJMA SOLIDARNOSTI OD NEKIH DRUGIH SRODNIH POJMOVA}

\section{TEOLOŠKI VID SOLIDARNOSTI}

Već je bilo riječi o tome da se pojam solidarnosti često poistovjećuje s nekim drugim srodnim pojmovima, kao što su, primjerice, altruizam, karitativnost, milosrđe, prijateljstvo, bratstvo itd. Uza sve teškoće koje stoje na putu povlačenja precizne i točne granice između navedenih pojmova i pojma solidarnosti, metodički razlozi upućuju na zahtjev da se ipak pokuša povući crta razgraničenja između njih. Ono što je zajedničko svim navedenim pojmovima jest činjenica da predstavljaju važne etičke vrijednosti. Dok se smisao pojmova altruizam, karitativnost, milosrđe vezuje za područje etike (napose kršćanske etike), dotle se smisao pojma solidarnosti širi i izvan granica etike te se javlja i u drugim područjima, kao npr. pravu, politici, sociologiji itd. Za razliku od altruizma i milosrđa koji se tiču prije svega unutarnjeg stava čovjeka, odnosno njegove svijesti, pojam solidarnosti osim poziva na svijest može se temeljiti i na altruizmu i na normi pozitivnog prava. Altruizam se shvaća najčešće kao nesebičnost, čovjekoljublje, ljubav prema drugome. To je etički termin koji označuje nesebičnu brigu za blagostanje ljudi i spremnosti na žrtvovanje svojih interesa za druge. ${ }^{30}$ 
Suprotno teoriji o svemoći i isključivosti egoizma (primjerice u filozofskoj poziciji Nietzschea i Stirnera), u altruističkoj se etici zastupa stav o jednom isto tako praizvornom i "prirodnom" altruizmu koji izrasta spontano i subjektivno iz čovjekova osjećanja povezanosti i pripadnosti ljudskom rodu. Altruističko odnošenje može proisteći i iz egoističkog nagona kao njegov nužni socijalni regulator u smislu održavanja jedne socijalne zajednice ili utvrđenja zajedničkog života (po prirodi egoističnih) pojedinaca.

"Altruizam je duhovni, teorijski i praktički korektiv utilitarizmu po kojemu je dobro poistovjećeno s korisnim (za pojedinca ili za čitavu zajednicu ili čovječanstvo)."31

S druge strane, pojam milosrđa ima dugu tradiciju. Njega susrećemo još kod starih Hebreja, a ne treba posebno ni isticati da milosrđe predstavlja i jedan od stupova stožera kršćanske etike.

"Za Izrael se milosrđe nalazi na stjecištu dviju mislenih struja: sućuti i vjernosti. Hebrejski izraz (ra'hamim) izražava nagonsku privrženost nekog bića drugomu. Drugi hebrejski izraz ('hesed) obično se na grčki jezik prevodi riječju koja također znači milosrđe ('eleos) i on sam po sebi označuje pijetet, svezu što sjedinjuje dva bića i uključuje vjernost. Time milosrđe dobiva čvrst temelj: ono više nije neki odjek nagonske dobrote, koja se može prevariti u svom predmetu i njegovoj naravi, već je svjesna 'htijena' dobrota; ona je dapače odaziv na unutarnju obvezu, vjernost samom sebi". ${ }^{32}$

Neki autori ukazuju da "milosrđe kao pojam iz biblijske, a onda i iz ukupne teološke perspektive nije moguće razumjeti bez ukazivanja na njegovu konstitutivnu povezanost s pojmom milosti." 33

Drugi, pak, poput Tamaruta, smatraju da je milosrđe tema koja povezuje Stari zavjet s Novim zavjetom.

“Milosrđe, dakle, nosi snažnu kristološku značajku, bitno određujući kršćansko shvaćanje čovjeka kako u osobnoj i individualnoj tako i u njegovoj eklezijalnoj, odnosno društvenoj dimenziji." ${ }^{34}$ U eksplikaciji pojma milosrđa valja posegnuti i za mišljenjem autora Vukovića i Bošnjakovića. Oni kažu da u "Novom zavjetu Božje milosrđe nadilazi granice izabranog naroda te u Isusu Kristu dobiva univerzalno značenje: proteže se na sve ljude te u konačnici, na čitavu stvorenu stvarnost." ${ }^{35}$ Suosjećanje za ovu dvojicu autora označuje aktivno sudjelovanje u situaciji drugoga, odnosno označuje stanje ganuća pred situacijom patnje druge osobe te spremnost djelovati i pomoći.

Cristoph Schönborn govoreći o milosrđu kaže da je ono danas svijetu potrebnije nego ikada te da je neodgodiva zadaća Crkve da ga naviješta. "Budući da je Božja ljubav izvor svega stvo-

31 Vladimir Filipović, Filozofijski rječnik, Matica hrvatska, Zagreb, 1965., str. 24.

32 Rječnik biblijske teologije, sv. 1., Kršćanska sadašnjost, Zagreb, 1969., str. 536.-537.

33 Mirko Divković, Latinsko-hrvatski rječnik, Kraljevska zemaljska tiskara, Zagreb, II. izdanje, 1900., str. 168. 
renoga bitka, ta se ljubav okreće svim stvorenjima bez iznimke, bez obzira koliko su daleko, koliko su bijedna i neznatna"36 - kaže Schönborn.

Špiro Marasović naglašava da je za "katoličku društvenu teoriju i za katoličku društvenu praksu, solidarnost do te mjere središnji pojam da su poznati njemački teolozi Hendrich Pesch, Gustav Gundlach i Oswald von Nell-Breunung nastojeći oponirati kapitalističkom individualizmu i socijalističkom kolektivizmu izgradili posebnu teoriju društva koju su nazvali solidarizam" ${ }^{37}$

Isti autor predlaže da u katoličkom socijalnom nauku kada je riječ o solidarnosti, valja naglasiti da ona uvijek znači solidarnost s onima koji zastupaju vrednote istinitoga dobra i svetoga, ako je o vrednotama riječ, odnosno solidarnost s onima koji su na bilo koji način u nečemu prikraćeni, ako je o društvenom životu riječ. ${ }^{38}$ Solidarnost se prema Marasoviću može vršiti: a) deklarativno b) efektivno za nekoga c) egzistencijalno (s nekim). Sukladno tome on zaključuje da "govoriti, dakle, o duhu solidarnosti možemo samo u ovom zadnjem slučaju, tj. u slučaju gdje je unutarnja opcija za drugoga u nevolji popraćena takvom vanjskom pomoći i podrškom da od onoga tko ih pruža, iziskuju određeni rizik". ${ }^{39}$

Solidarnost se na taj način pokazuje ne samo u riskantnom davanju materijalnih dobara, nego i u riskantnom postojanju uz drugoga, za drugoga i s drugim. ${ }^{40}$

Rebeka Anić ustvrđuje da papa Ivan Pavao II. o solidarnosti najviše govori u enciklikama Solicitudo rei socialis, Centesimus Annus te u Evangelium vitae. Obveza solidarnosti odnosi se na sve članove crkve. Papa posebno naglašava skrb za najpotrebitije: bolesne, ograničene, izrabljivane, siročad, stare ljude, djecu, omladinu, zatvorenike i uopće ljude na rubu društva. ${ }^{41}$

Stjepan Baloban smatra da u suvremenom društvu postoje različiti oblici solidarnosti: “(...) osobna solidarnost, obiteljska solidarnost, gospodarska solidarnost, radnička solidarnost, solidarnost dobrovoljnih društava, solidarnost javnih institucija i međunarodna solidarnost”. ${ }^{42}$

Kompendij socijalnog nauka Crkve smatra da se danas čovječanstvo nalazi pred tri ključna izazova: 1) izazov same istine o biti - čovjek 2) shvaćanja i upravljanja pluralizmom i različitostima na svim razinama 3) izazov globalizacije koja ima šire i dublje značenje od čisto gospodarstvenog.

Socijalni nauk Crkve upućen je svakom kršćaninu prema kompetencijama, karizmama, službama i poslanju navještanja, koji su svakom svojstveni.

Kao trajna načela socijalnog nauka Crkve spominju se sljedeća: riječ je o načelu dostojanstva ljudske osobe, o općem dobru te o načelima supsidijarnosti i solidarnosti. S tim u

36 Cristoph kardinal Schönborn, Našli smo milosrđe, Kršćanska sadašnjost, 2010., Zagreb, str. 35.

37 Špiro Marasović, Pokazatelji duha solidarnosti među franjevcima i franjevkama, Zbornik Kultura solidarnosti, Franjevački institut za kulturu mira, Split, 1999., str. 97.

38 Ibidem, str. 101.

39 Isto, str. 103

40 Isto, str. 109.

41 Rebeka Anić, Solidarnost u učenju Ivana Pavla II., Zbornik Kultura solidarnosti, Franjevački institut za kulturu mira, Split, str. 146.

42 Stjepan Baloban, Solidarnost u svjetlu socijalnog nauka Crkve, Centar za promicanje socijalnog nauka Crkve, Kršćanska sadašnjost, 2004., str. 52. 
svezi “solidarnost pruža osobitu važnost unutarnjoj društvenosti ljudske osobe, jednakosti sviju u dostojanstvu i pravima, zajedničkome putu ljudi i naroda prema sve osvjedočenijem jedinstvu". ${ }^{43}$

Solidarnost se primarno očituje pod dvama komplementarnim aspektima: pod aspektom socijalnog načela i pod aspektom moralne kreposti.

Kompendij socijalnog nauka Crkve uči da solidarnost u njezinoj vrijednosti socijalnog načela koje uređuje institucije i na osnovi kojega se strukture grijeha, koje vladaju odnosima među osobama i narodima, moraju prevladati i preobraziti u strukture solidarnosti ili prikladnim promjenama zakona, tržišnih pravila i propisa.

Solidarnost je također prava i istinska moralna krepost, a ne osjećaj neke neodređene sućuti ili površnog ganuća zbog patnji tolikih ljudi bliskih ili udaljenih. Naprotiv, to je čvrsta i postojana odlučnost zauzeti se za opće dobro, to jest za dobro svih i svakoga, jer svi smo mi uistinu za sve odgovorni. Solidarnost se tako promeće na rang temeljne socijalne kreposti, jer se smješta u dimenziju pravde koja je krepost okrenuta općem dobru. "Poruka socijalnog nauka o solidarnosti ističe činjenicu da postoje uske sveze između solidarnosti i općeg dobra, solidarnosti i opće namjene dobara solidarnosti i zakonitosti među ljudima i narodima, solidarnosti i mira u svijetu". ${ }^{44}$ Kompendij naglašava i činjenicu da "načelo solidarnosti zahtijeva da ljudi našega doba više njeguju svijest o dugu što ga imaju, u odnosu prema društvu u koje su uključeni”, ${ }^{45}$ što jako podsjeća na misao L. Bourgeoisa. U svjetlu vjere solidarnost inklinira tome da samu sebe transcendira da poprimi specifično kršćanske razmjere posvemašnje dobrohotnosti, opraštanja i pomirenja.

U doba globalizacije posebice treba isticati solidarnost među naraštajima. "Solidarnost među naraštajima zahtijeva da se u globalnome planiranju djeluje prema načelu opće namjene dobara koje moralno nedopustivim i ekonomski kontraproduktivnim čini prebacivanje sadašnjih troškova na buduće naraštaje." ${ }^{46}$

Nikola Vukoja smatra da "solidarnost nije naredba, nije ni samo goruća potreba sadašnjeg trenutka, nego je to pitanje autentičnosti ljudskoga i kršćanskoga života, a duhovnost se bavi upravo autentičnim kršćanskim životom" ${ }^{47}$ On vrši i vrlo iscrpnu raščlambu socijalnih enciklika papâ počam od Rerum Novarum do enciklika pape Ivana Pavla II. i to pod vidom duhovne dimenzije. Drugi vatikanski koncil dovodi do produbljivanja značenja solidarnosti napose u pastoralnoj konstituciji Gaudium et spes. Prelazi zatim na papu Pavla VI. (1963.-1978.), te papu Ivana Pavla II. (1978.-2005.), posebice njegove enciklike Laborem exercens, Sollicitudo rei socialis i Centesimus annus.

Vukoja u zaključnim razmatranjima ustvrđuje da "jednako je bjelodano kako se od solidarnosti kao ontološke dimenzije ljudske naravi uvijek iznova dolazi do njezine kristocentrične i povijesno-spasenjske dimenzije te kako se od solidarnosti ako je unutarnja zakonitost ili

\footnotetext{
43 Papinsko vijeće "Iustitia et pax”, Kompendij socijalnog nauka Crkve, Kršćanska sadašnjost, Zagreb, 2005., str. 147.

44 Ibidem, str. 149

45 Isto, str. 150.

46 Isto, str. 203.-264.

47 Nikola Vukoja, Neki elementi duhovne dimenzije solidarnosti u socijalnim dokumentima Crkve, Bogoslovska smotra, KBFZ, 75 (2005) br. 4, str. 1111.
} 
norma, osobito kod Pija XII., ako je moralna dužnost i obveza, osobito kod Pavla VI., stiže do solidarnosti kao vrijednosti i kreposti koja je kadra u sebi obuhvatiti specifične značajke pravednosti i štoviše i same kršćanske ljubavi kod pape Ivana Pavla II". ${ }^{48}$

Zanimljivu raščlambu za razumijevanje solidarnosti daje papa Benedikt XVI. On pojam solidarnosti dovodi u svezu s pojmom bratstva. U eksplikaciji toga pojma Ratzinger vidi da "proširena ideja bratstva gotovo nužno stvara dvije različite zone etosa, etos prema unutra ('među braćom') i etos prema van". ${ }^{49}$

Izraelski pojam bratstva označava bratstvo od zajedničkog oca, naime Boga koji "nije samo Bog Izraelov, nego jedini Bog uopće i utoliko nije samo otac Izraelov, nego otac svih". ${ }^{50}$

Ratzingerova egzegeza pojmova "brat" i "bratstvo" ide od helenističke misli, preko prosvjetiteljstva i Francuske revolucije te drži da se u odnosu između onih kojih je "malo" i "mnogih" očituje i istinska mjera katoliciteta. Ratzinger drži da "prema njezinu vanjskom broju ona nikada neće postati 'katolička' to jest sveobuhvatna, nego će u konačnici ostati malo stado, čak i više nego što to statistika daje naslutiti, a koja dakako, laže time što braćom naziva mnoge, koji su u stvari tek nominalni i prividni kršćani” ${ }^{51}$

Tonči Matulić daje zanimljiv obol razumijevanju pojma solidarnost. On napominje da Sveto pismo expresis verbis uopće ne spominje pojam solidarnosti. Drugo, pojam solidarnosti je povijesno-ideološki neodvojivo vezan uz povijesni proces sekularizacije započet Francuskom revolucijom 1789. godine. Matulić smatra da se "bratstvo" izgubilo u literaturi, palo u povijesni zaborav i sustavno je zanemarivano. Stoga on drži da "u tzv. post-kršćanskoj i post-metafizičkoj eri ideja solidarnosti bi trebala nadomjestiti izgubljenu ideju bratstva te ispraviti i nadoknaditi sve negativne posljedice prouzročene zaboravom na nju". ${ }^{52}$

Matulić smatra da teološko određenje solidarnosti kršćanske poruke, niti može niti smije zaobići primjer Isusa Krista, kao onoga u kome je sadržana punina solidarnosti. Njegovo otvoreno, konkretno, nepatvoreno, jednom riječju autentično zauzimanje za slabe, bolesne i umiruće, marginalizirane, napuštene, siromašne, grešnike, zalutale, dezorijentirane, izolirane i potlačene, bez obzira na nacionalnu, dobnu, spolnu, rasnu, klasnu i društvenu pripadnost, a kako i o čemu nas izvještavaju četiri evanđelja, predstavlja polazište za sadržajno osmišljavanje solidarnosti ${ }^{53}$ - tvrdi Matulić.

U eksplikaciji pojma solidarnosti valja ga dovesti u koleraciju i s pojmom karitativnosti. Taj pojam također ima svoju povijest.

Karitativnost vuče korijen od latinske riječi caritas-atis, f. (carus), što znači skupoća, nestašica novca, ali i poštovanje, štovanje, odanost, ljubav, nesebičnost, dobrohotnost itd. ${ }^{54}$

\footnotetext{
48 Isto, str. 1150.

49 Joseph Ratzinger, Kršćansko bratstvo, Kršćanska sadašnjost, Zagreb, 2008., str. 12.

$50 \quad$ Ibidem, str. 13.-14.

51 Ibidem, str. 81.

52 Tonči Matulić, Skica teološkog utemeljenja ideje solidarnosti, Bogoslovska smotra, br. 74 (2004), br. 2, KBF Zagreb, str. 437.

53 Ibidem, str. 452

Mirko Divković, Latinsko-hrvatski rječnik, Kraljevska zemaljska tiskara, Zagreb, II. izd., 1900., str. 168.
} 
Karitas znači još i vršenje djelotvorne ljubavi prema bližnjem; gozbu prvih kršćana na koju su se primali prijatelji i siromasi; ono što se daje iz ljubavi, badava, bez obveze i milostinja. ${ }^{55}$ U francuskom jeziku charité označuje svetu i svjetovnu ljubav, djevičansku ljubav, prisnu nježnost i prijateljstvo. ${ }^{56}$

Dok svi ti pojmovi nose u sebi značajnu mjeru spiritualnog i interiorizirajućeg, pojam solidarnosti posjeduje u sebi naglašen profani naboj. Ono po čemu se solidarnost u značajnoj mjeri razlikuje od svih spomenutih pojmova jest i njezino obilježje uzajamnosti ili mutualizma, što je poglavito karakteristično za tzv. "primarnu" solidarnost, unutar koje davanje, darivanje podrazumijeva obvezu vraćanja, o čemu je nadahnuto pisao Marcel Mauss, u svojoj knjizi “Esej o daru". Ipak treba ustvrditi da solidarnost nije isto što i uzajamnost te da ne počiva na rimskoj formuli "do ut des".

Ako pak solidarnost promatramo kao oblik socijalne politike u širem smislu riječi, možemo u odnosu prema pojmu karitas primijetiti još neke sličnosti, odnosno razlike. Sličnosti se manifestiraju u tome što i jedan i drugi pojam imaju zadaću da budu u službi pomoći ljudima. Nadalje, i solidarnost i karitativnost obično potiče isti motiv, a to je čovjekoljublje, osjećaj dužnosti, socijalni interes itd. Oba pojma imaju zajednički cilj, a taj je unaprjeđenje boljitka siromašnih klasa društva (iako se, kao što smo naglasili, solidarnost može odnositi ne samo na stanje oskudice nego i rasta). Karitas se obično vrši u ime ljubavi (milosrđa), a solidarnost u ime pravednosti. Nadalje, socijalna politika u svom širem značenju usmjerena je na zaštitu velikih skupina ljudi, dok karitas uvijek ima u vidu individualni slučaj.

Svakako su od zanimanja i stajališta o solidarnosti aktualnog pape Franje. On ustvrđuje da je riječ "solidarnost" pomalo otrcana i katkad se pogrešno shvaća, ali označava mnogo više od nekoga povremenog čina darežljivosti. Taj pojam podrazumijeva stvaranje novog mentaliteta koji razmišlja u terminima zajedništva i prioriteta života svih nad prisvajanjem dobara od strane nekolicine. Papa kaže da je "solidarnost riječ koje se razvijeni svijet plaši. Nastoje ju ne izgovoriti. Solidarnost je za njih gotovo psovka. Ali to je naša riječ" 57 - rezolutan je papa i zaključuje "da ne gradi i ne vodi boljem svijetu kultura egoizma, individualizma, koja često upravlja našim društvom, nego kultura solidarnosti. A kultura solidarnosti sastoji se u tome da u drugome ne gledamo suparnika ili broj, nego brata. A svi smo mi braća."58

Papa smatra da je potrebno na nov način razmišljati o solidarnosti. “Tom riječi 'solidarnost' kojoj je svijet ekonomije nesklon i ne gleda dobro na nju - kao da je loša riječ - treba vratiti zasluženo mjesto u društvu. Solidarnost nije tek jedan od stavova, nije socijalna milostinja, već je društvena vrijednost"59 - ustvrđuje papa Franjo.

\section{SOLIDARNOST I HRVATSKO DRUŠTVO}

\footnotetext{
55 Hrvatska kršćanska terminologija, Knjižnica "Marija”, Split, 1976., str. 122.

56 Dictionnaire de Spiritualité, Beauchesne, Paris, t. II, 1953., str. 508.-510.

57 Papa Franjo, Crkva milosrđa, Kršćanska sadašnjost, Zagreb, 2014., str. 127.

58 Ibidem, str. 142.-143.

59 Isto, str. 148.
} 
Od osobitog značenja je promišljanje problematike solidarnosti unutar suvremenog hrvatskog društva koje još liječi rane i traume nanesene velikosrpskom agresijom 90-ih godina. $S$ tim u svezi autori poput Balobana smatraju da se solidarnost u bivšem sustavu dozivala iz vrha države. "Takva solidarnost asistencijskog tipa vodila je depersonalizaciji osoba i skupina, stvarajući mentalitet - ne treba si međusobno pomagati jer probleme treba ionako riješiti 'država'."

Isti autor napominje kako u suvremenom društvu postoje različiti oblici solidarnosti: “(...) osobna solidarnost, obiteljska solidarnost, gospodarska solidarnost, radnička solidarnost, solidarnost dobrovoljnih društava, solidarnost javnih institucija i međunarodna solidarnost."61

Autorica Melanija Strika smatra da se temeljne zapreke razvoju solidarnosti u hrvatskom društvenom kontekstu mogu sumirati u nekoliko problemskih skupina:

1) naslijeđeni vrijednosni sustav iz socijalističkog razdoblja koji uključuje elemente amoralnog familizma i autoritarnosti

2) niska razina povjerenja na mikro razini (međuljudski odnosi) i makro razini (institucije sustava i mediji)

3) niska razina participacije hrvatskih građana u građanskim inicijativama i niska razina raspoloživih za dobrovoljni rad

4) zakonske i administrativne zapreke udruživanju građana (prenormiranost, normativni optimizam)

5) zapreke koje proizlaze iz društvenih činjenica i koje izravno utječu na društvenu strukturu (proces tranzicije). ${ }^{6}$

I Špiro Marasović ustvrđuje da rezultati nekih istraživanja pokazuju kako je i individualno i grupno prakticiranje solidarnosti kao konkretnog zauzimanja za opće dobro u Hrvatskoj na prilično niskoj razini, što se u potpunosti poklapa s prethodnom spoznajom o niskoj razini solidarnosti i općega dobra kao motivacijskog čimbenika. Isti autor tvrdi da "svaka solidarnost, naime, ne pripada općem dobru, ali svako opće dobro predstavlja solidarnost". ${ }^{63}$

Općenito dade se ustvrditi kako je solidarnost na makro planu očekivano u Europi nešto niža nego solidarnost na mikro planu. Komparativna studija vrednota pokazala je da na mezzo razini europski građani pokazuju visoku razinu osjetljivosti za starije, nezaposlene, imigrante te bolesne i nemoćne u njihovim zemljama, odnosno za one kategorije koje kao ranjive i rizične skupine mogu upasti u siromaštvo i druge oblike socijalne isključenosti.

“Tijekom Domovinskog rata (1991.-1995.) bilo je mnogo neformalnih oblika solidarnosti. No nakon njegova završetka stvari se mijenjaju u suprotnom smjeru, tako da ponovno jača

60 Stjepan Baloban, Solidarnost u svjetlu socijalnog nauka Crkve, u: O solidarnosti i supsidijarnosti u Hrvatskoj, Centar za promicanje socijalnog nauka Crkve, Kršćanska sadašnjost, Zagreb, 2004., str. 2.

61 Ibidem, str. 52.

62 Melanija Strika, Perspektive međuodnosa solidarnosti, povjerenja i dobrovoljnosti u hrvatskom društvu, Bogoslovska smotra, KBF Zagreb, 75 (2005), br. 4, str. 1152.

63 Špiro Marasović, Međuodnos solidarnosti i općega dobra u Hrvatskoj, Bogoslovska smotra, KBF Zagreb, 75 (2005), br. 4, str. 992. 
pristup solidarnosti prema kojemu bi država sa svojim institucijama trebala pokazati daleko veći angažman u solidarnosti, a drugi oblici ostaju po strani”. ${ }^{64}$

Istraživanje je pokazalo "da su solidarniji i socijalno osjetljiviji oni hrvatski građani koji su manje permisivni u socijalnoj i individualnoj sferi morala”. ${ }^{65}$

Značajno je da se u Hrvatskoj pokazalo da se na osobnoj razini religioznost ne pokazuje kao važan čimbenik promocije solidarnosti i socijalne osjetljivosti. Pritom, primjećuje se veliki "vakuum" između osobne solidarnosti koja je iznimno visoka i institucionalne solidarnosti koja je znatno niža.

Zaključno, možemo ustvrditi nekoliko napomena. Naime, temeljna nakana ovoga rada bila je da ustvrdi puno i pravo značenje pojma solidarnosti. U tom smislu pošli smo od etimologije samog pojma, pokazujući da je riječ o pojmu koji iako novovjekovan ima dugu povijest koja svoje korijene vuče u doba Rimskog prava. Raščlamba je pokazala da je pojam solidarnosti prema svojoj strukturi ambivalentan te ga treba lučiti od drugih srodnih pojmova kao što su bratstvo, karitativnost, empatija, milosrđe etc. Solidarnost i u turbulentnim globalizacijskim vremenima, obilježenim fragmentacijom, atomizacijom, dominantnim liberalnim individualizmom, etičkim relativizmom, globalnim ekonomskim nejednakostima, ostaje značajna društvena silnica, esencija katoličkog socijalnog nauka i važan etičko-teološko-sociološki pojam usmjeren integraciji društvenog tkiva.

Pokazali smo shvaćanja brojnih hrvatskih mislitelja - teologa, sociologa, pravnika i ukazali na značaj pojma solidarnosti za suvremeno hrvatsko društvo ali i za svijet u cjelini. U situaciji kada hrvatsko društvo i svijet prolaze kroz, prije svega, negativne posljedice neoliberalnog kapitalizma koji je iznjedrio nove oblike socijalne nejednakosti, u kojima polovica svjetskog pučanstva živi u siromaštvu, smatramo da solidarnost i u novim društvenim uvjetima mora imati značajnu kohezijsku ulogu. Pritom smatramo da solidarnost ne smije biti prepuštena području socijalne politike, nego mora postati dio moralne savjesti svakog pojedinca i društvenih skupina, posebice onih koji imaju u odnosu na one koji su stjecajem različitih okolnosti postali društveno marginalizirani, pogotovo motreći tu činjenicu iz perspektive da je svaki život ponajprije Božji dar i da ga kao takvoga moramo štititi i poduprijeti. U tom smislu posebno značenje dobiva zauzimanje pape Franje za imigrante, siromašne ili na drugi način deprivirane i marginalizirane pojedince, društvene skupine i narode.

64 Stjepan Baloban, Ivan Štengl, Solidarnost i socijalna (ne)osjetljivost, u: Pero Aračić; Josip Baloban; Stjepan Baloban, U potrazi za identitetom. Komparativna studija vrednota: Hrvatska i Europa, prir. Josip Baloban, Golden marketing - tehnička knjiga, Zagreb, 2005., str. 192. 


\section{LITERATURA}

1. Anić, Rebeka, Solidarnost u učenju Ivana Pavla II., zbornik Kultura solidarnosti, Franjevački institut za kulturu mira, Split,1999.

2. Baloban, Stjepan, Solidarnost u svjetlu socijalnog nauka Crkve, Centar za promicanje socijalnog nauka Crkve, Kršćanska sadašnjost, Zagreb, 2004.

3. Baloban, Stjepan, Štengl, Ivan, Solidarnost i socijalna (ne osjetljivost), u Aračić, Pero; Baloban, Josip; Baloban, Stjepan, U potrazi za identitetom, komparativna studija vrednota: Hrvatska i Europa, pr. Baloban, Josip. Golden marketing-tehnička knjiga, Zagreb, 2005.

4. Bernsdorf, Wilhelm, Bülow, Friedrich, Wörterbuch der Soziologie, Ferdinande Enke Verlag, Stuttgart, 1955.

5. Boljšaja sovjetskaja enciklopedija: Gosudarstvenoe naučnoe izdateljstvo, II. izd., Moskva, 1957.

6. Bosanac Milan; Mandić Oleg; Petković Stanko, Rječnik sociologije i socijalne psihologije, Informator, Zagreb, 1977.

7. Brunkhorst, Hauke, Solidarnost. Od građanskog prijateljstva do globalne pravne zajednice, Multimedijalni institut Beograd/Zagreb, 2004.

8. Cooley, Robert Angell, Social integration, International Encyclopaedia of the Social Sciences The Macmillan Company and The Free Press, vol. VII, New York, 1972.

9. Dictionnaire de Spiritualité, Beauchesne, t. II, Paris, 1953.

10. Divković, Mirko, Latinsko- hrvatski rječnik, Kraljevska zemaljska tiskara, II. izd., Zagreb, 1900.

11. Durkheim, Emile, De la division du travail social, Presses Universitaires de France, Paris, 1960.

12. Filipović, Vladimir, Filozofijski rječnik, Matica hrvatska, Zagreb, 1965.

13. Grand Larousse Encyclopédique, Librairie Larousse, t. 9, Paris, 1964.

14. Hrvatska kršćanska terminologija, Knjižnica “Marija”, Split, 1976.

15. Klaić, Bratoljub, Rječnik stranih riječi, Nakladni zavod Matice hrvatske, Zagreb, 1984.

16. Laruque, Pierre, Les Classes Sociales, Presses Universitaires de France, Paris, 1959.

17. Marasović, Špiro, Međuodnos solidarnosti i općega dobra u Hrvatskoj, Bogoslovska smotra, KBF, 75, br. 4 (2005), Zagreb.

18. Marasović, Špiro, Pokazatelji duha solidarnosti među franjevcima i franjevkama, zbornik Kultura solidarnosti, Franjevački institut za kulturu mira, Split, 1999.

19. Matulić, Tonči, Skica teološkog utemeljenja ideje solidarnosti, Bogoslovska smotra, 74, br. 2 (2004), $\mathrm{KBF}$, Zagreb.

20. Nicoleti, Gioacchino, Solidarismo, u Novissimo Digesto Italiano, Unione tipografico- Editrice Torinese, vol. XVII, 1970, Torino.

21. Opća enciklopedija, Jugoslavenski leksikografski zavod, III. izd., 1981., Zagreb.

22. Papa Franjo, Crkva milosrđa, Kršćanska sadašnjost, 2014., Zagreb.

23. Papinsko vijeće "Iustitia et pax": Kompendij socijalnog nauka Crkve, Kršćanska sadašnjost, 2005., Zagreb.

24. Perić, Berislav, Solidarizam u teoriji prava, Zbornik radova Pravnog fakulteta u Zagrebu, 3-4/1954., Zagreb.

25. Pusić, Eugen, Razvedenost i povezanost, Encyclopaedia moderna, 1974., Zagreb.

26. Ratzinger, Joseph, Kršćansko bratstvo, Kršćanska sadašnjost, 2008., Zagreb. 
27. Rječnik biblijske teologije, Kršćanska sadašnjost, sv. 1., 1969., Zagreb.

28. Savin, Ksenija, Solidarnost i altruizam, Sociološki pregled, 2-3/1974., Beograd.

29. Schönborn, Christoph, Našli smo milosrđe, Kršćanska sadašnjost, 2010., Zagreb.

30. Sociološki leksikon, Savremena administracija, 1985., Beograd.

31. Strika, Melanija, Perspektive međuodnosa solidarnosti, povjerenja i dobrovoljnosti u hrvatskom društvu, Bogoslovska smotra, 75, br. 4 (2005) KBF, Zagreb.

32. Supek, Rudi, Integracijski i dezintegracijski procesi u društvu "prijelaznog perioda", Sociologija, 2-3/1983., Beograd.

33. Tamarut, Anton, Božje milosrđe u nauku poslijekoncilskih papa, Bogoslovska smotra, 86/2016., $\mathrm{KBF}$, Zagreb.

34. Todorović, Aleksandar, Solidarnost i radnička svijest, u zborniku: Solidarnost i samoupravljanje, Centar za političke studije, Novi Sad, 1971.

35. Webster's C. Merriam company, Springfield, Massachusetts, USA, 1961.

36. Vierkandt, Alfred, Solidarität, u Bernsdorf und Bülow: Wörterbuch der Soziologie, Ferdinand Enke Verlag, 1955., Stuttgart.

37. Vukoja, Nikola, Neki elementi duhovne dimenzije solidarnosti u socijalnim dokumentima Crkve, Bogoslovska smotra, br. 4/2005., KBF, Zagreb.

38. Vuković, Davor, Bošnjaković, Josip, Empatija, suosjećanje i milosrđe: Psihološke i teološke perspektive, Bogoslovska smotra, 86/2016., KBF, Zagreb. 


\section{SOLIDARITY - THE KEY CONCEPT OF THE CATHOLIC SOCIAL TEACHING}

\section{Summary}

The paper deals with the concept of solidarity as a key concept of Catholic social teaching. The paper has been a logical continuation of the author's solidarity issue consideration since 1980s, in particular the issue of synergetic effect of the sociological legal and theological insights. The latter flourished in Croatia in particular in the period between 1995-2005 when theological thought contributed significantly to understanding of solidarity and its conceptual differentiation from similar concepts such as charity, compassion, brotherhood etc. In the field of social sciences solidarity has shown itself as an autonomous and important concept and from a theological viewpoint it is the most important virtue of Catholic social teaching. The etymological insight into solidarity, its social role and its integrational potential are indisputable.

Keywords: $\quad$ solidarity, Catholic social teaching, brotherhood, compassion, charity 